\title{
Genetic associations between reproductive and linear-type traits of Holstein cows in Brazil
}

\author{
Tatiana Prestes Almeida', Elisandra Lurdes Kern¹, Darlene dos Santos Daltro', José Braccini \\ Neto $^{2}$, Concepta McManus ${ }^{3}$, André Thaler Neto ${ }^{4}$, Jaime Araujo Cobuci ${ }^{*}$
}

\footnotetext{
${ }^{1}$ Universidade Federal do Rio Grande do Sul, Programa de Pós-graduação em Zootecnia, Porto Alegre, RS, Brazil.

${ }^{2}$ Universidade Federal do Rio Grande do Sul, Faculdade de Agronomia, Departamento de Zootecnia, Porto Alegre, RS, Brazil.

${ }^{3}$ Universidade de Brasilia, Brasilia, DF, Brazil.

${ }^{4}$ Universidade do Estado de Santa Catarina, Departamento de Produção Animal e Alimentos, Florianópolis, SC, Brazil.
}

\begin{abstract}
This study aimed to estimate heritability, genetic, and residual correlations between reproductive traits such as age at first calving, calving interval, dry period, and first service period and linear type traits measured in Holstein cows born between the years 1990 and 2008 in Brazil. The (co)variance components were estimated by restricted maximum likelihood, using the MTDFREML software. The heritability for reproductive traits and linear-type traits ranged from 0.02 to 0.03 and from 0.07 to 0.40 , respectively. Estimates of genetic correlations between reproductive and linear-type traits ranged from -0.23 (top line) to 0.28 (angularity) to age at first calving, from -0.54 (final score) to 0.34 (foot angle) to calving interval, from -0.23 (angularity) to 0.56 (stature) to dry period, and from -0.52 (final score) to 0.36 (height udder) to first service period. Direct selection for any of the reproductive traits implies low genetic gains by virtue of their low heritabilities. Among the linear-type traits, the final score, chest width, top line, angularity, teat length, udder attachment, rear teat placement were highlighted as good auxiliary traits to improve reproductive efficiency of Holstein cows in Brazil. The simultaneous selection for reproductive and linear-type traits can lead a higher genetic progress in the reproductive traits.
\end{abstract}

Key Words: age at first calving, dairy cattle, genetic parameters, reproductive efficiency

\section{Introduction}

Reproductive efficiency is a major factor affecting profitability in dairy cattle. For many years, dairy cattle selection has been based on improving production traits, such as milk production, leading to a decrease of reproductive performance in dairy cows (Rennó et al., 2003; Pérez-Cabal et al., 2006).

The main difficulty in the genetic selection of reproductive traits is their low heritability, which ranges from 0.04 (dry period) to 0.18 (age at first calving) (Brcko et al., 2010; Eghbalsaied, 2011). This low heritability delays the genetic gain with these traits. Genetic gain may be obtained through indirect selection based on traits correlated with the reproductive traits and measured more

Received: April 13, 2016

Accepted: November 18, 2016

*Corresponding author: jaime.cobuci@ufrgs.br

http://dx.doi.org/10.1590/S1806-92902017000200002

How to cite: Almeida, T. P.; Kern, E. L.; Daltro, D. S.; Braccini Neto, J.; McManus, C.; Thaler Neto, A. and Cobuci, J. A. 2017. Genetic associations between reproductive and linear-type traits of Holstein cows in Brazil. Revista Brasileira de Zootecnia 46(2):91-98.

Copyright (C) 2017 Sociedade Brasileira de Zootecnia. This is an Open Access article distributed under the terms of the Creative Commons Attribution License (http://creativecommons.org/licenses/by/4.0/), which permits unrestricted use, distribution, and reproduction in any medium, provided the original work is properly cited. easily in the life of the animal, such as the type traits (Berry et al., 2004). The simultaneous selection for two or more traits can lead a higher genetic progress in the traits of interest.

Type traits have been associated with other economic traits to improve cows conformation and functional and reproductive traits, so that the animal has a body structure that can support the challenges of increasing production (Miglior et al., 2005). A considerable number of type traits displays favorable genetic relationships with calving interval, showing that indirect selection for type traits can be used to obtain genetic progress for some reproductive traits (Dal Zotto et al., 2007; Makgahlela et al., 2009).

Type traits have been used as a tool to indirect selection to improve reproductive efficiency. This study aimed to estimate the genetic and residual parameters as heritability, genetic, and residual correlations between reproductive and type traits in Brazilian Holstein cows.

\section{Material and Methods}

Linear classification records for type and reproductive traits from Holstein cows were provided by the Associação Brasileira de Criadores de Bovinos da Raça Holandesa (ABCBRH) and its state affiliates, between 1995 and 2010 totaling 113,000 cows born between 1990 and 2008 . 
The classifications regarding type traits were obtained from direct or visual measurement of the morphology of cows expressed on a biological point scale ranging from 1 to 9 , according to the Canadian model, and included morphological evaluation of 21 traits, divided into seven sections. The type traits studied were: conformation (stature, top line, weight, chest width, body depth, and loin strength), rump (angle and width), legs and feet (foot angle, bone quality, and side view of rear legs), front udder (fore udder attachment, fore teat placement, and teat length), rear udder (height, width, and placement of the teats of the rear udder), mammary system (depth, udder texture, and udder cleft), and dairy form (angularity), as well as the final score, which expresses the balance between the sections. The reproductive traits evaluated were: age at first calving, first calving interval, first dry season duration, and first service period.

Consistency of records for the type and reproductive traits was performed separately. For consistency in the type traits, the cows had to be classified from their first to third lactation and aged from 20 to 67 months. Cows without pedigree information, with a final score of less than 60 or greater than 90 points, with different dates of birth, same date of calving in different lactation numbers, or more than one classification were excluded from the database.

To minimize the environmental influence on the analysis, ten lactation classes at classification (first to tenth month of lactation) and four classification periods were formulated: summer (January to March), fall (April to June), winter (July to September), and spring (OctoberDecember). Contemporary groups for type traits were formulated based on herd, year, and classification period, each one containing at least three cows. Additionally, each cow's father was required to have at least two daughters in at least two different herds. After verifying the consistency of data, four different databases were formed; the number of records for the bivariate analysis, including these traits, ranged from 14.714 for first service period to 31.231 for age at first calving (Table 1).

The estimation of (co)variance components was conducted between reproductive- and linear-type traits using multi-trait models. These models included the fixed effects of contemporary group, period of classification, classifier, lactation classes at classification, and age at calving (covariate as linear and quadratic terms) for type traits and the fixed effects of contemporary groups and age at calving (covariate as linear and quadratic terms) for reproductive traits. The animal and residual random effects were common to both models. The matrix model used to estimate the components of (co)variance between reproductive- and linear-type traits can be represented by:

$$
\left[\begin{array}{l}
y_{1} \\
y_{2}
\end{array}\right]=\left[\begin{array}{ll}
X_{1} & 0 \\
0 & X_{2}
\end{array}\right] *\left[\begin{array}{l}
\beta_{1} \\
\beta_{2}
\end{array}\right]+\left[\begin{array}{ll}
Z_{1} & 0 \\
0 & Z_{2}
\end{array}\right] *\left[\begin{array}{l}
a_{1} \\
a_{2}
\end{array}\right]+\left[\begin{array}{l}
e_{1} \\
e_{2}
\end{array}\right]
$$

in which yi is the vector of observations of the $i$-th type $(i=1)$ and reproductive traits $(i=2) ; \beta_{i}$ is the vector of fixed effects of the $i$-th trait; $\mathrm{a}_{\mathrm{i}}$ is the random animal vector of the $i$-th trait; $\mathrm{e}_{\mathrm{i}}$ is the vector of residual effects of the $i$-th character; $X_{i}$ and $Z_{i}$ are incidence matrices relating to the observations of $i$-th trait in the fixed and random effects of animal, respectively.

It is assumed that:

$$
\operatorname{var}\left[\begin{array}{l}
a_{1} \\
a_{2} \\
e_{1} \\
e_{2}
\end{array}\right]=\left[\begin{array}{cccc}
g_{11} A & g_{12} A & 0 & 0 \\
g_{21} A & g_{22} A & 0 & 0 \\
0 & 0 & r_{11} I & r_{12} I \\
0 & 0 & r_{21} I & r_{22} I
\end{array}\right] \text {, }
$$

in which $g_{i j}$ are the elements of the matrix $G$ (co)additive genetic variance or animal effects, with each element defined as: $g_{11}$ is the additive genetic variance for the direct effect of the linear type trait $(\mathrm{i}=1) ; \mathrm{g}_{12}=\mathrm{g}_{21}$ is the additive genetic covariance between the two traits; $g_{22}$ is the additive genetic variance for direct effect of reproductive trait $(\mathrm{i}=2)$; $\mathrm{A}$ is the numerator of the matrix coefficients of kinship between animals; $r_{i j}$ are the elements of the matrix $R$, related to the (co)variance of the residual effects, with each element defined as: $r_{11}$ is the residual variance for the linear type trait $(i=1) ; r_{22}$ and $r_{21}$ are the residual covariances between reproductive and type traits; $r_{22}$ is the residual variance for the reproduction trait $(\mathrm{i}=2)$; and $\mathrm{I}$ is the identity matrix which assumes the independence of errors with the same variance.

Estimates of the components of (co)variance were performed by the method of restricted maximum likelihood using MTDFREML software (Boldman et al., 1995), considering the convergence criterion of $10^{-9}$.

Table 1 - Number of cows, dams, sires, contemporary groups (CG), and herds in the Brazilian Holstein database for each reproductive trait analyzed

\begin{tabular}{lcccc}
\hline Database & $\begin{array}{c}\text { Age at first } \\
\text { calving }\end{array}$ & $\begin{array}{c}\text { Calving } \\
\text { interval }\end{array}$ & $\begin{array}{c}\text { Dry } \\
\text { period }\end{array}$ & $\begin{array}{c}\text { First service } \\
\text { period }\end{array}$ \\
\hline Cows & 31231 & 22837 & 17600 & 14714 \\
Dams & 22611 & 17416 & 13858 & 11762 \\
Sires & 1245 & 1039 & 896 & 792 \\
CG (reproductive) & 4446 & 3488 & 2771 & 2246 \\
CG (type) & 2378 & 1920 & 1587 & 1370 \\
Herds & 410 & 333 & 283 & 273 \\
\hline
\end{tabular}




\section{Results and Discussion}

The average age at first calving was 26.86 months (Table 2). This was similar to the one observed by Wolff et al. (2004). According to Campos and Lizieire (2005), age at first calving from 23 to 25 months can be considered indicative of reproductive efficiency of Holstein cows. The age at first calving, despite being intensively selected in Holsteins, deserves attention in animal breeding programs, once it can influence other reproductive and productive traits. Krpálková et al. (2014) demonstrated that cows with earlier calving have fewer days open, reduced service numbers, shorter interval to conception, as well as increased milk production in the second and third lactations.

The average calving interval was approximately 14 months (Table 2), similar to the reported by Zafar et al. (2008) and Grebogi et al. (2008), who found 14.3 and 13 months, respectively, in Holstein cows. According to Bahonar et al. (2009) a period of 12 to 13 months, can be considered optimal for dairy cows. Longer intervals, above 14 months, are related to decreased milk production and with increased reproductive problems such as abortion (Leite et al., 2001). According to Ferreira and Miranda (2007), the reduction of one month in the calving interval leads to an $8.3 \%$ increase in milk production and in the number of calves per cow. Therefore, a higher calving rate, a reduced number of dry cows, and a higher number of lactation cows are expected in the herd.

The average dry period was about 61 days (Table 2). Several studies have recommended a period of 60 days as ideal, thus maximizing production over the life of the cow (Kuhn et al., 2006; Rangel et al., 2009; Mello, 2014). However, some studies comparing different dry periods have indicated that shortening the dry period (around 40 dry days) can improve the profitability in the herd. The benefits of reduced dry period are: higher milk produced in the current lactation and less changes in nutritional

Table 2 - Mean, standard deviation (SD), and heritability $\left(\mathrm{h}^{2}\right)$ for reproductive traits obtained through bivariate analysis with all type traits ${ }^{1}$ in dairy Brazilian Holstein cows

\begin{tabular}{lcc}
\hline Trait & Mean \pm SD & $\mathrm{h}^{2} \pm \mathrm{SD}$ \\
\hline Age at first calving (months) & $26.86 \pm 4.05$ & $0.02 \pm 0.01$ \\
Calving interval (months) & $14.66 \pm 3.58$ & $0.03 \pm 0.01$ \\
Dry period (days) & $60.99 \pm 16.05$ & $0.03 \pm 0.01$ \\
First service period (days) & $120.17 \pm 58.00$ & $0.03 \pm 0.01$ \\
\hline
\end{tabular}

${ }^{1}$ Stature, top line, weight, chest width, body depth, loin strength, rump angle, rump width, foot angle, bone quality, side view of rear legs, fore udder attachment, teat placement, teat length, udder height, udder width, fore teat placement, udder depth, udder texture, udder cleft, angularity, and final score. management practices, decreasing metabolic disorders (Gulay et al., 2003; Rastani et al., 2005; Watters et al., 2008).

Shoshani et al. (2014) reported that cows with 60-day dry period produced more milk in the next lactation than cows with 40 days, but less in the current lactation. These authors did not find difference in the fat, protein, and colostrum quality between the two periods. However, cows from the 40-day dry period showed minor calving to conception interval and lactation duration.

The average time between calving to first conception first service period - was approximately 120 days (Table 2). This is higher than recommended for obtaining adequate reproductive performance in dairy cattle, between 60 and 90 days, which allows for a calving interval around 13 to 14 months (Pereira et al., 2000). Longer first service period, over 90 days, is associated with shorter length of productive life in dairy cows (Sewalem et al., 2008), lower milk production, and increasing fertility problems (Ferreira and Miranda, 2007), consequently leading to decrease in profitability in dairy cattle.

In general, the heritabilities were low for all reproductive traits (Table 2). These values indicate that the reproductive traits are greatly influenced by environmental factors and, therefore, direct selection for these traits involves slow genetic progress, which support the hypothesis that fertility traits are difficult to use directly as selection criteria. Low values were also reported by Eghbalsaied (2011) and Silva et al. (2001) for the calving interval (0.06 and 0.03) and age at first calving (0.03 and 0.02). Pereira et al. (2000) and Silva et al. (2001) reported heritability near the nullity for dry period (from 0.00 to 0.04 ). Moreover, moderate to low estimates for age at first calving (0.13) and calving interval (0.18) were reported by McManus et al. (2008) for Holstein cows.

The low estimates can be due to low additive genetic variance of these traits (Silva et al., 2006; Pereira et al., 2000) and also because these traits reflect, in part, the personal decisions of producers as well as other reproductive and nutritional management factors.

The average scores for linear-type traits ranged from 4.5 (teat placement) to 7.2 (height) (Table 3). The final score showed a value above the minimum established as ideal, indicating certain harmony between linear-type traits in Brazilian Holsteins as also highlighted by Kern et al. (2015).

The heritability for type traits showed small variations according to the different reproductive traits studied. (Table 3). The higher heritability values were observed for stature, rump width, and teat length traits. These higher heritability values indicate that genetic gains of these type 
traits are more influenced by genetic factors compared with the type traits with low heritability. Lower heritabilities were observed for foot angle and udder texture. These results are similar to the ones reported by Dal Zotto et al. (2007), for stature, udder texture, and foot angle in bivariate analysis involving calving interval with type traits. Campos et al. (2012) and Kern et al. (2015) also reported that foot angle and udder texture were the traits that showed the lowest heritability in Holstein cows in Brazil, using a multi-trait model, including production and longevity traits, respectively.

The residual correlations were next to nullity (Table 4). These values suggest that reproductive and type traits are not influenced by the same environmental factors and improvement in the environmental management in relation to the type traits do not increase the efficiency of reproductive traits.

Considering that the effect of residual correlation in the current generation will not affect the next generation, the attention should be focused on the genetic correlation between traits, being this effect passed on to future generations. The importance of correlation studies between traits is related to the possibility of selection for just one when two traits are correlated genetically. The choice of which to use depends on factors such as heritability, cost, ease of collection, and time for obtaining the trait or measure.

In general, the genetic correlations obtained were moderate to low (Table 4 and Figures 1 and 2). The magnitudes of the genetic correlations ranged from -0.54 (final score with calving interval) to 0.56 (stature with dry period).

Considering the age at first calving, the strongest correlations were observed with angularity (0.28), top line $(-0.23)$, chest width $(-0.18)$, body weight $(-0.16)$, bone quality (0.16), and foot angle (0.15) (Figure 1 and Table 4). This genetic correlation values indicate that genetic selection to cows with good angularity, bone quality, and foot angle can result in increased age at first calving. Conversely, most type traits were correlated negatively with age at

Table 3 - Mean, standard deviation (SD), ideal score for type traits, and heritability for type traits obtained through bivariate analysis with reproductive traits in Brazilian Holstein dairy cows

\begin{tabular}{|c|c|c|c|c|c|c|}
\hline \multirow{2}{*}{ Section/trait } & \multirow{2}{*}{ Mean \pm SD } & \multirow{2}{*}{ Ideal score } & \multicolumn{4}{|c|}{ Heritability $^{1}$} \\
\hline & & & $\mathrm{AFC}$ & $\mathrm{CI}$ & DP & $\mathrm{SP}$ \\
\hline \multicolumn{7}{|l|}{ Conformation } \\
\hline Stature & $7.2 \pm 1.31$ & 7 & 0.39 & 0.39 & 0.40 & 0.39 \\
\hline Top line & $5.2 \pm 1.05$ & $5-6-7$ & 0.21 & 0.21 & 0.21 & 0.20 \\
\hline Weight & $6.9 \pm 1.23$ & 9 & 0.25 & 0.25 & 0.25 & 0.27 \\
\hline Chest width & $5.8 \pm 1.23$ & 7 & 0.19 & 0.18 & 0.19 & 0.20 \\
\hline Body depth & $6.2 \pm 1.09$ & 7 & 0.21 & 0.20 & 0.20 & 0.21 \\
\hline Loin strength & $6.3 \pm 1.38$ & 9 & 0.21 & 0.20 & 0.19 & 0.19 \\
\hline \multicolumn{7}{|l|}{ Rump } \\
\hline Angle & $5.0 \pm 1.02$ & $5-6-7$ & 0.31 & 0.29 & 0.27 & 0.28 \\
\hline Width & $6.5 \pm 1.22$ & 9 & 0.32 & 0.30 & 0.29 & 0.28 \\
\hline \multicolumn{7}{|l|}{ Feet and legs } \\
\hline Foot angle & $5.1 \pm 1.24$ & 7 & 0.08 & 0.09 & 0.09 & 0.09 \\
\hline Bone quality & $6.6 \pm 1.36$ & 9 & 0.20 & 0.19 & 0.20 & 0.22 \\
\hline Side view of rear legs & $5.5 \pm 1.13$ & 5 & 0.17 & 0.16 & 0.16 & 0.17 \\
\hline \multicolumn{7}{|l|}{ Fore udder } \\
\hline Attachment & $6.0 \pm 1.52$ & 9 & 0.20 & 0.19 & 0.19 & 0.21 \\
\hline Teat placement & $4.5 \pm 1.17$ & 5 & 0.27 & 0.27 & 0.26 & 0.27 \\
\hline Teat length & $5.2 \pm 1.09$ & 5 & 0.33 & 0.32 & 0.26 & 0.33 \\
\hline \multicolumn{7}{|l|}{ Rear udder } \\
\hline Height & $6.4 \pm 1.35$ & 9 & 0.18 & 0.16 & 0.18 & 0.18 \\
\hline Width & $6.0 \pm 1.48$ & 9 & 0.14 & 0.17 & 0.15 & 0.15 \\
\hline Teat placement & $6.2 \pm 1.16$ & $5-6$ & 0.15 & 0.16 & 0.15 & 0.16 \\
\hline \multicolumn{7}{|l|}{ Mammary system } \\
\hline Depth & $4.8 \pm 1.15$ & $5-6$ & 0.25 & 0.23 & 0.24 & 0.25 \\
\hline Texture & $6.8 \pm 1.22$ & 9 & 0.07 & 0.09 & 0.10 & 0.10 \\
\hline Cleft & $6.4 \pm 1.56$ & 9 & 0.13 & 0.14 & 0.14 & 0.16 \\
\hline \multicolumn{7}{|l|}{ Dairy form } \\
\hline Angularity & $6.3 \pm 1.21$ & 9 & 0.20 & 0.15 & 0.18 & 0.15 \\
\hline Final score & $81.24 \pm 3.16$ & $>80$ & 0.12 & 0.17 & 0.12 & 0.14 \\
\hline
\end{tabular}

AFC - age at first calving; CI - calving interval; DP - dry period; SP - first service period.

${ }^{1}$ The standard deviations of heritability ranged from 0.00 to 0.022 for all type traits. 
first calving; thus if the indirect genetic selection use these traits, such as top line, chest width, and body weight, higher efficiency can be obtained for age at first calving, ie, higher cow precocity at first calving. Given the low correlation with final scores $(-0.10)$, indirect selection to age at first calving based on final score will result in slow genetic advances. Wenceslau et al. (2000) reported moderate to low and negative genetic correlations between age at first calving and type traits in Gir dairy cows, except for body depth, which showed a positive correlation (0.25).

The genetic correlations between calving interval with type traits, ranged from -0.54 (final score) to 0.34 (foot angle) (Table 4 and Figure 1). Indirect selection for final score $(-0.54)$, chest width $(-0.26)$, teat length $(-0.21)$, and body depth $(-0.20)$ can be used as tool for the selection of cows with smaller calving interval. The other type traits, such as foot angle, stature, and side view of rear legs also showed moderate genetic correlation with calving interval. However, these values are positive, suggesting that selection for reproduction using these type traits would significantly increase the calving interval of cows. The genetic correlations between calving interval with rump angle, rump width, and udder height were null and/or near to nullity, suggesting that selection for these type traits would not add genetic gains to reproductive traits as calving interval.

Most type traits related to the mammary system and udder sections, with exception of teat length and placement, showed unfavorable association with calving interval. This result may be considered questionable, as animals with good udders are generally in good health and, therefore, expected to have fewer fertility problems. A possible explanation for the unfavorable genetic correlations between the mammary traits with calving interval is due to the fact that selection for increased milk production, for long years (which is unfavorably correlated to fertility), has resulted in unfavorable genetic trends in fertility, as the increase in calving interval (Veerkamp et al., 2001; Wall et al., 2005).

Silva et al. (2015) also reported similar results for genetic association between foot angle, chest width, rump angle, body depth with calving interval. However, these

Table 4 - Genetic and residual correlations between linear- and reproductive-type traits in Brazilian Holstein cows according to conformation, rump, feet and legs, fore udder, rear udder, mammary system, dairy form, and final score

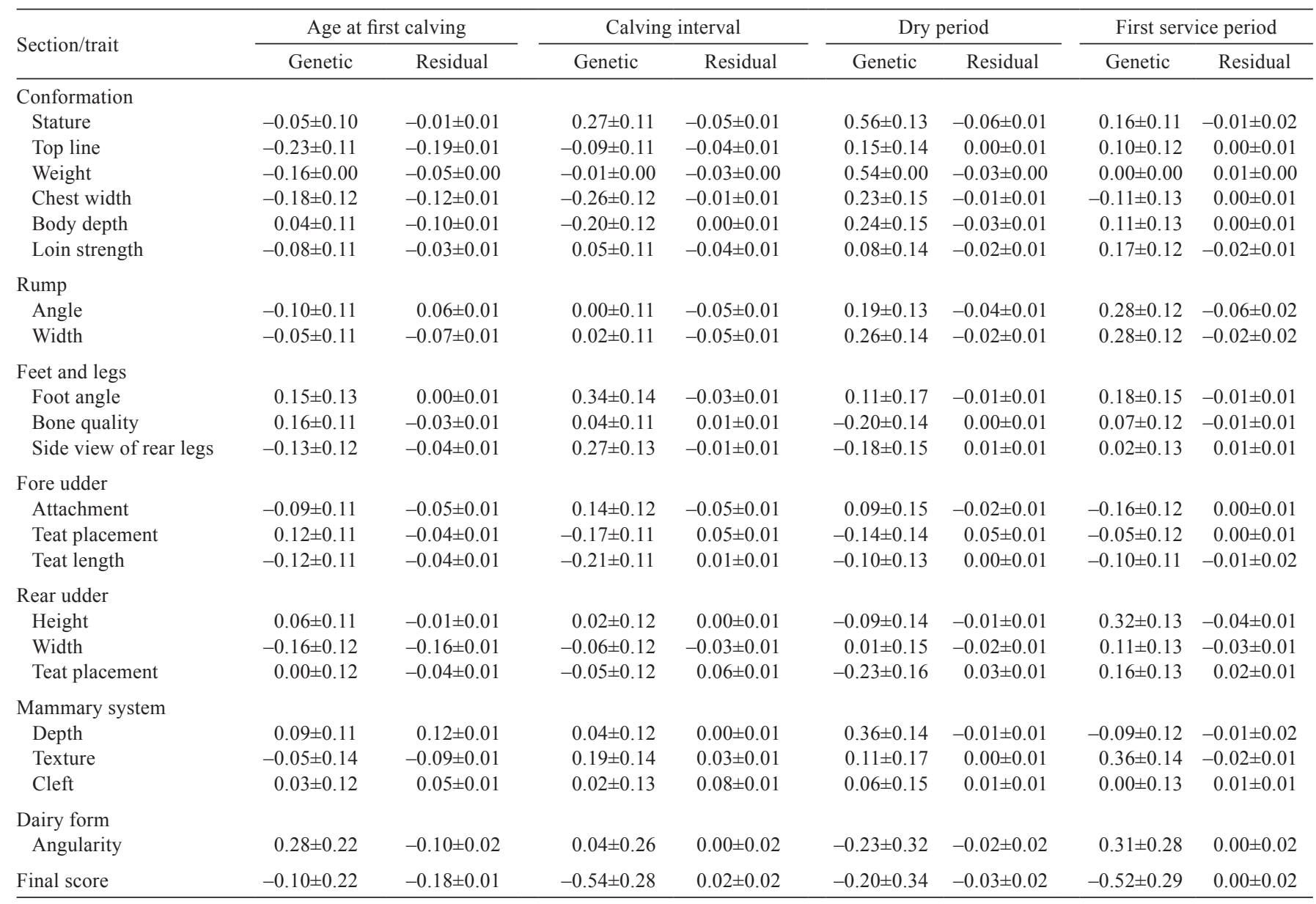


authors and Makgahlela et al. (2009), indicate that selection for rump width can improve the calving interval in dairy cows, which differs from our study and from the Wall et al. (2005) study, in which no genetic association was found between these two traits.

Genetic correlations between type traits and dry period showed values varying from -0.23 (teat placement rear) to 0.56 (stature) (Table 4 and Figure 2). The strongest positive genetic correlation of dry period were observed in stature (0.56), body weight (0.54), udder depth (0.36), and rump width (0.26). However, despite moderate, this genetic correlation is not desirable, because the selection to improve this type traits also lead to increased dry period. The negative genetic correlations, i.e. desirable with dry period, were observed in rear teat placement $(-0.23)$, angularity $(-0.23)$, final score $(-0.20)$, and bone quality $(-0.20)$, suggesting that indirect selection for these type traits can result in reduced dry period.

The major proportion of genetic correlations between first service period and type traits were positive and moderate to low, as udder texture (0.36), udder height $(0.32)$, angularity (0.31), rump angle, and width (0.26), which do not provide desirable association with this reproductive trait, leading to the increase in service period if indirect selection is directed toward this type traits (Table 4 and Figure 2). However, we can highlight the final score $(-0.52)$ and, in lesser extension, the udder attachment $(-0.16)$ as possible indirect predictors to improve the first service period.

The final score showed favorable genetic correlations between the first service period, dry period, and calving interval, suggesting that it can be used as an indirect prediction to increase the reproductive efficiency in Brazilian Holsteins cows. Moreover, according to Campos et al. (2012), the final score reflects the genetic harmony among the all type traits and suggests that these traits can be used as selection criteria to promote improvements in various type traits due to the strong genetic correlation among them.

The traits from the conformation sections demonstrated favorable associations with age at first calving and calving interval, but insignificant genetic association between dry period and first service period. However, Pryce et al. (2001) and Berry et al. (2003) reported that cows with good
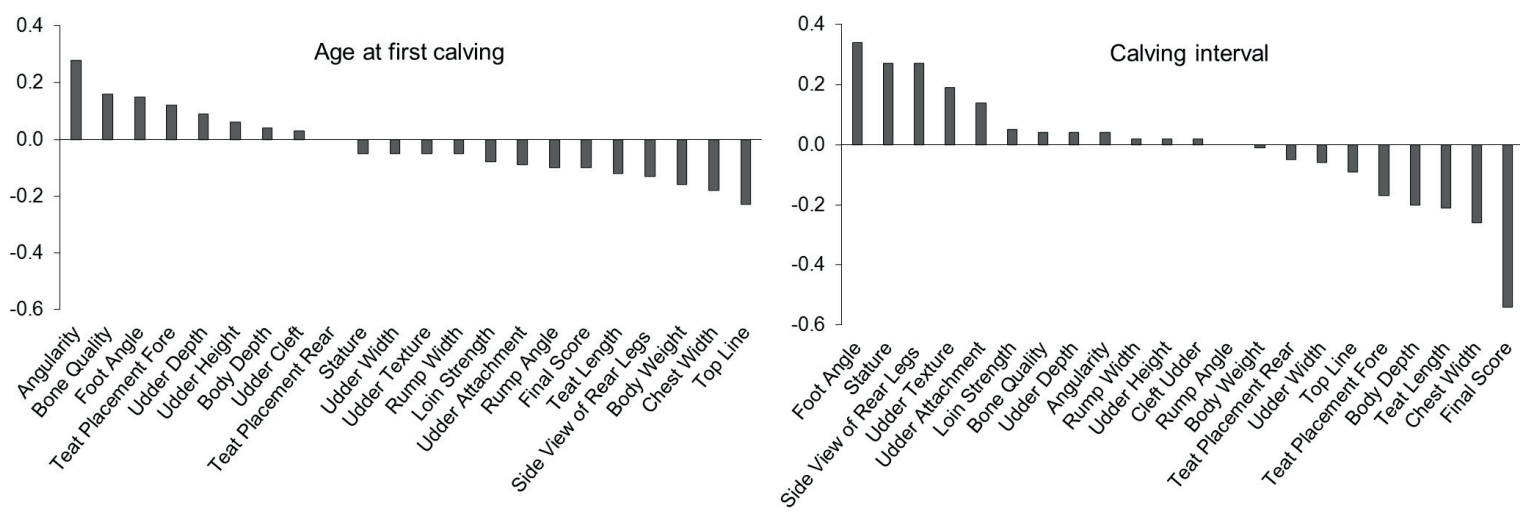

Figure 1 - Genetic correlations between age at first calving and calving interval with 21 type traits plus the final score.
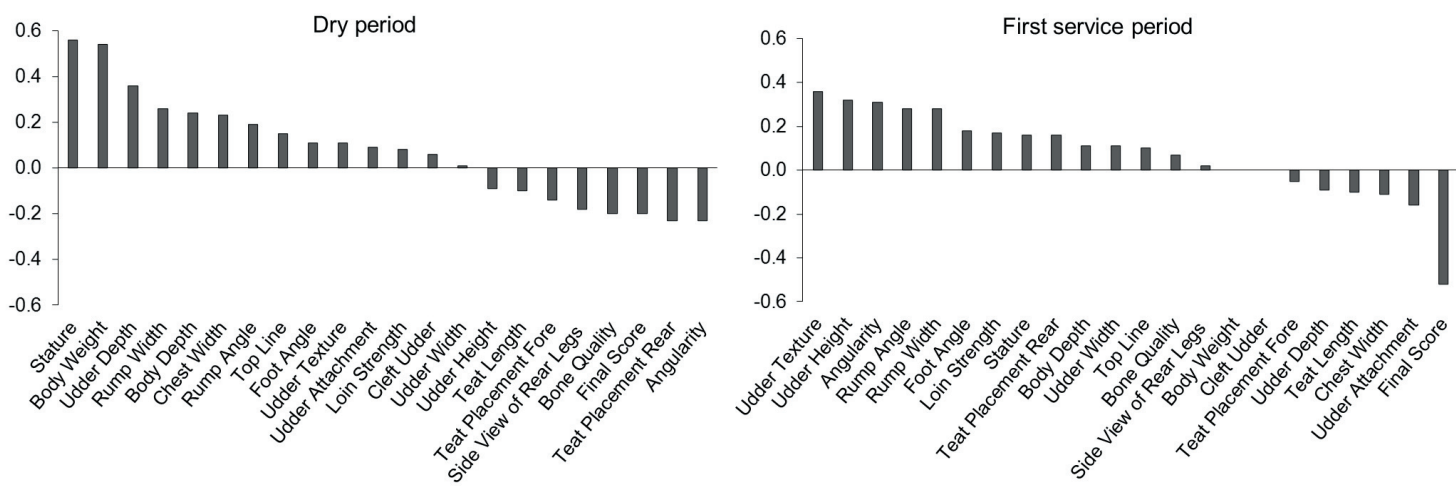

Figure 2 - Genetic correlations between dry period and first service period with 21 type traits plus the final score. 
conformation and body weight showed a favorable genetic correlation with first service period, with values varying from -0.54 to -0.18 . According to Veerkamp et al. (2001), conformation traits are widely used in many species to assess body composition and energy balance status of animals.

A possible explanation for the unfavorable association between most traits related to udder and mammary system sections (except for teat placement, teat length, and udder attachment) with the reproductive traits may be due to a favorable genetic association of these type traits with the milk production. According to Roxstrom et al. (2001) and Evans et al. (2002), selection for milk production has led to decreased reproductive efficiency of animals.

The top line and chest width with age at first calving, final score and chest width with calving interval, rear teat placement and angularity with dry period and final score, and udder attachment with first service period had the highest and most favorable genetic correlations and can be used as auxiliary traits for selection of improvement in reproductive traits. Final score may be indicated for use in indirect selection due to its moderate to high genetic correlation with all reproductive traits studied. The magnitudes of genetic associations obtained in this study reinforce the possibility of practicing indirect selection based primarily on breeding values and indicate the necessity to design a national selection index to increase reproductive efficiency in Brazilian Holstein cows.

\section{Conclusions}

Estimated genetic parameters show very low heritabilities for fertility traits. Despite the relatively low heritability of many fertility traits, an opportunity exists to improve reproductive performance through selection for a combination of interrelated traits. The type traits final score, chest width, top line, angularity, teat length, udder attachment, and rear teat placement have potential to be used as auxiliary traits for indirect selection for reproductive efficiency of Holstein cows managed in Brazilian herds. The simultaneous selection for reproductive- and lineartype traits cited above can lead a higher genetic progress in the reproductive traits.

\section{References}

Bahonar, A. R; Azizzadeh, M.; Stevenson, M.A.; Vojgani, M. and Mahmouudi, M. 2009. Factors affecting days open in Holstein dairy cattle in Khorasan Razavi Province, Iran; A cox proportional hazard model. Journal of Animal and Veterinary Advances $8: 747-754$
Berry, D. P.; Buckley, F; Dillon, P; Evans, R. D.; Rath, M. and Veerkamp, R. F. 2003. Genetic relationships among body condition score, body weight, milk yield, and fertility in dairy cows. Journal of Dairy Science 86:2193-2204.

Berry, D. P.; Buckley, F.; Dillon, P.; Evans, R. D. and Veerkamp, R. F. 2004. Genetic relationships among linear type its, milk yield, body weight, fertility and somatic cell count in primiparous dairy cows. Irish Journal of Agricultural and Food Research 43:161-176.

Boldman, K. G.; Kriese, L. A.; Van Vleck, L. D.; Van Tassell, C. P. and Kachman, S. D. 1995. A manual for use of MTDFREML: a set of programs to obtain estimates of variances and covariances [DRAFT]. U. S. Department of Agriculture, Agricultural Research Service. 120p. Available at: < ftp://aipl.arsusda.gov/pub/outgoing/ $\mathrm{mtdfreml/mtdfrman.pdf>}$. Accessed on: May 15, 2013.

Brcko, C. C.; Araújo, C. V.; Araújo, S. I.; Renno, F. P. and Marcondes, C. R. 2010. Estimação de parâmetros genéticos da produção leiteira e idade ao primeiro parto de vacas Pardo-Suíças por meio de inferência bayesiana. Revista de Ciências Agrárias 1:59-63.

Campos, O. F. and Lizieire, R. S. 2005. Criação de bezerras em rebanhos leiteiros. Embrapa Gado de Leite, Juiz de Fora.

Campos, R. V.; Cobuci, J. A.; Costa, C. N. and Braccini Neto, J. 2012. Genetic parameters for type traits in Holstein cows in Brazil. Revista Brasileira de Zootecnia 41:2150-2161.

Dal Zotto, R.; Marchi, M. D. E.; Dalvit, C.; Cassandro, M.; Gallo, L. and Carnier, P.; Bittante, G. 2007. Heritabilities and genetic correlations of body condition score and calving interval with yield, somatic cell score, and linear type traits in Brown Swiss cattle. Journal Dairy Science 90:5737-5743.

Eghbalsaied, S. 2011. Estimation of genetic parameters for 13 female fertility indices in Holstein dairy cows. Tropical Animal Health and Production 43:811-816.

Evans, R. D.; Buckley, F.; Dillon, P. and Veerkamp, R. F. 2002. Genetic parameters for production and fertility in spring-calving Irish dairy cattle. Irish Journal of Agricultural and Food Research 41:43-54.

Ferreira, A. M. and Miranda, J. E. C. 2007. Medidas de eficiência da atividade leiteira: índices zootécnicos para rebanhos leiteiros. Embrapa Gado de Leite, Juiz de Fora. (Embrapa Gado de Leite. Documentos, 54).

Gulay, M. S.; Hayen, M. J.; Bachman, K. C.; Belloso, T.; Liboni, M. and Head, H. H. 2003. Milk production and feed intake of Holstein cows given short (30-d) or normal (60-d) dry periods. Journal of Dairy Science 86:2030-2038.

Grebogi, A.; Ostrensky, A.; Pohl, F.; Almeida, R.; Weiss, R. R.; Kozicki, L. E.; Breda, J. C. and Giacomeli, A. M. 2008. Impacto da idade ao parto no desempenho produtivo e reprodutivo em vacas Holandesas primíparas. Archives of Veterinary Science 13:22-25.

Kern, E. L.; Cobuci, J. A.; Costa, C. N.; McManus, C. M. and Braccini Neto, J. 2015. Genetic association between longevity and linear type traits of Holstein cows. Scientia Agricola 72:203-209.

Krpálková, L.; Cabrera, V. E.; Vacek, M.; Štípková, M.; Stádník, L. and Crump, P. 2014. Effect of prepubertal and postpubertal growth and age at first calving on production and reproduction traits during the first 3 lactations in Holstein dairy cattle. Journal of Dairy Science 97:3017-3027.

Kuhn, M. T.; Hutchison, J. L. and Norman, H. D. 2006. Effects of length of dry period on yields of milk fat and protein, fertility and milk somatic cell score in the subsequent lactation of dairy cows. Journal of Dairy Research 73:154-162.

Leite, T. E.; Moraes, J. C. F. and Pimentel, C. A. 2001. Eficiência produtiva e reprodutiva em vacas leiteiras. Ciência Rural $31: 467-472$.

Makgahlela, M. I.; Mostert, B. E. and Banga, C. B. 2009. Genetic relationships between calving interval and linear type traits in 
South African Holstein and Jersey cattle. South African Society for Animal Science 39:90-92.

Mello, R. R. C. 2014. Perdas reprodutivas em fêmeas bovinas. Revista Agropecuária Científica no Semiárido 10:07-23.

McManus, C.; Louvandini, H.; Falcão, R. A.; Garcia, J. A. S. and Saueressing, M. G. 2008. Parâmetros reprodutivos para gado Holandês em confinamento total no Centro-oeste do Brasil. Ciência Animal Brasileira 9:272-283.

Miglior, F.; Muir, B. L. and Van Doormaal, B. J. 2005. Selection indices in Holstein cattle of various countries. Journal of Dairy Science 88:1255-1263.

Pereira, I. G.; Gonçalves, T. M.; Oliveira, A. I. G. and Teixeira, N. M. 2000. Fatores de variação e parâmetros genéticos dos períodos de serviço e seco em bovinos da raça holandês no Estado de Minas Gerais. Revista Brasileira de Zootecnia 29:1005-1013.

Pérez-Cabal, M.; García, C.; González-Recio, O. and Alenda, R. 2006. Genetic and phenotypic relationships among locomotion type traits, profit, production, longevity, and fertility in Spanish dairy cows. Journal of Dairy Science 89:1776-1783.

Pryce, J. E.; Coffey, M. P. and Simm, G. 2001. The relationship between body condition score and reproductive performance. Journal of Dairy Science 84:1508-1515.

Rangel, A. H. N.; Guedes, P. L. C.; Albuquerque, R. P. F.; Novais, L. P. and Lima Júnior, D. M. 2009. Desempenho produtivo leiteiro de vacas guzerá. Revista Verde 4:85-89.

Rastani, R. R.; Grummer, R. R.; Bertics, S. J.; Gumen, A.; Wiltbank, M. C.; Mashek, D. G. and Schwab, M. C. 2005. Reducing dry period length to simplify feeding transition cows: Milk production, energy balance, and metabolic profiles. Journal of Dairy Science 88:1004-1014.

Rennó, F. P.; Araújo, C. V.; Pereira, J. C.; Freitas, M. S.; Torres, R. A.; Rennó, L. N.; Azevêdo, A. G. and Kaiser, F. R. 2003. Correlações genéticas e fenotípicas entre características de conformação e produção de leite em bovinos da raça Pardo-Suíça no Brasil. Revista Brasileira de Zootecnia 32:1419-1430.

Roxstrom, A.; Strandberg, E.; Berglund, B.; Emanuelson, U. and Philipsson, J. 2001. Genetic and environmental correlations among female fertility traits and milk production in different parities of Swedish red and white dairy cattle. Acta Agriculturae Scandinavica - Animal Science 51:7-14.

Sewalem, A.; Miglior, F.; Kistemaker, G. J.; Sullivan, P. and Van Doormaal, B. J. 2008. Relationship between reproduction traits and functional longevity in Canadian dairy cattle. Journal of Dairy Science 91:1660-1668.

Silva, M. V. G. B.; Martinez, M. L.; Bergmann, J. A. G. 2001. Desempenho reprodutivo e produtivo da raça holandesa em alguns estados brasileiros. Revista Ceres 48:293-309.

Silva, M. V. G. B.; Cobuci, J. A.; Ferreira, W. J.; Oliveira, P. R. P.; Machado, M. A. and Ferreira, C. P. 2006. Efeitos genéticos e de ambiente em um rebanho do Ecótipo Mantiqueira - características reprodutivas. Ciência e Agrotecnologia 30:522-528.

Silva, R. P. A.; Thaler Neto, A.; Cobuci, J. A.; Valloto, A. A.; Horst, J. A.; Ribas Neto, P. G. 2015. Correlações genéticas entre algumas características de tipo e intervalo de partos em vacas da raça Holandesa. Arquivo Brasileiro de Medicina Veterinária e Zootecnia 67:166-172.

Shoshani, E.; Rozen, S. and Doekes, J. J. 2014. Effect of a short dry period on milk yield and content, colostrum quality, fertility, and metabolic status of Holstein cows. Journal of Dairy Science 97:2909-2922.

Veerkamp, R. F.; Koenen, E. P. C. and De Jong, G. 2001. Genetic correlations among body condition score, yield, and fertility in first-parity cows estimated by random regression models. Journal of Dairy Science 84:2327-2335.

Wall, E.; White, I. M.; Coffey, M. P. and Brotherstone, S. 2005. The relationship between fertility, rump angle, and selected type information in Holstein-friesian cows. Journal of Dairy Science $88: 1521-1528$

Watters, R. D.; Guenther, J. N.; Brickner, A. E.; Rastani, R. R.; Crump, P. M.; Clark, P. W. and Grummer, R. R. 2008. Effects of dry period length on milk production and health of dairy cattle. Journal of Dairy Science 91:2595-2603.

Wenceslau, A. A.; Lopes, P. S.; Teodoro, R. L.; Verneque, R. S.; Euclydes, R. F.; Ferreira, W. J. and Silva, M. A. 2000. Estimação de parâmetros genéticos de medidas de conformação, produção de leite e idade ao primeiro parto em vacas da raça Gir Leiteiro. Revista Brasileira de Zootecnia 29:153-158.

Wolff, M. C. C.; Monardes, H. G. and Ribas, N. P. 2004. Environmental factors that influence the age at the first calving, days open and calving interval in Holstein cows of the Castrolanda, state of Paraná. Arquives of Veterinary Science 9:35-41.

Zafar, A. H.; Ahmad, M. and Rehman, S. U. 2008. Study of some performance traits in sahiwal cows during different periods. Pakistan Veterinary Journal 28:84-88. 